$\overline{\text { Note }}$

\title{
Evaluation of an Enzyme-Linked Fluorescent Assay for the Detection of Listeria monocytogenes from Food
}

\author{
SHIGEKO UEDA*, AND YOSHIHIRO KUWABARA \\ Laboratory of Hygiene, Kagawa Nutrition University, 3-9-21, Chiyoda, Sakado-shi, Saitama 350-0214, Japan
}

Received 20 March, 2010/Accepted 25 May, 2010

\begin{abstract}
The VIDAS Listeria monocytogenes II (LMO2) method, which is an automated enzymelinked fluorescent immunoassay (ELFA), was used for rapidly, specifically and sensitively detecting $L$. monocytogenes in food samples. All $31 \mathrm{~L}$. monocytogenes strains examined gave positive results. The other bacterial species except Salmonella showed completely negative results, but it was suspected that Salmonella spp. had given a false-positive reaction to the assay. As the detectable limit of the assay was $10^{6} \mathrm{cfu} / \mathrm{ml}$ in a food suspension, food samples were required to be enriched in order to increase the number of the bacteria to the detectable limit. However, the ELFA was reconfirmed to be applied satisfactorily as a rapid and precise method for the detection of $L$. monocytogenes in various food samples, even if the culture had to be enriched for $12 \mathrm{~h}$ prior to the assay.
\end{abstract}

Key words : Listeria monocytogenes / Enzyme-linked fluorescent assay/Food.

Listeria monocytogenes is widespread in nature, being associated with plants, soil, water, feed, and animals. It has also been recovered from the stool samples of an estimated 1 to $10 \%$ of people who are healthy (Farber and Peterkin, 1991). At the same time, L. monocytogenes is indicated as an important foodborne pathogen. Foodborne listeriosis has been caused by the ingestion of contaminated food such as cheese, meat, ice cream and fish (McLauchlin, 1997). In Japan, a food poisoning outbreak incriminating the ingestion of natural cheese in 2001 has been suspected as the only case of foodborne listeriosis (Kawamoto et al., 2004). The prevalence of this bacterium in numerous kinds of food ranges from $13 \%$ in raw meat to $3 \%$ in dairy products, $11 \%$ in fresh vegetables, and $3 \%$ in seafood (Luchansky et al., 2005). Also, the levels in ready-to-eat foods are known to be lower than those in various raw food materials. Farber and Peterkin (1991) summarized that the $L$. monocytogenes in various meat and dairy products was usually present at levels of 1.0 to $3.0 \mathrm{log}$ $\mathrm{cfu} / \mathrm{g}$, and Gombas et al. (2003) reported a prevalence of $1.82 \%$ and levels of $<0.3$ most probable number (MPN) $/ \mathrm{g}$ to $1.5 \times 10^{5} \mathrm{cfu} / \mathrm{g}$ in different types

*Corresponding author. Tel/Fax : + 81-49-282-7343. of ready-to-eat food. To ensure food safety and maintain public health, it is necessary to monitor low levels of the bacteria accurately.

In this study, the VIDAS Listeria monocytogenes II (LMO2) method was used for rapidly, specifically and sensitively detecting $L$. monocytogenes in food samples. The VIDAS LMO2 assay is an automated enzyme-linked fluorescent immunoassay (ELFA) for the detection of the bacterium (Silbernagel et al., 2004; Oktay et al., 2006). Once the automated assay is complete, a positive or negative result can be decided within $70 \mathrm{~min}$. In the present study, the presence and/or absence of $L$. monocytogenes in the test suspension was distinguished by using an automated fluorescent immunoassay instrument (miniVIDAS; bioMerieux) and the VIDAS LMO2 kit (bioMerieux) according to the protocol of the manufacturer. For the bacteriological examination, Brain Heart Infusion (BHI; Difco), UVM broth (Oxoid), Fraser broth (bioMerieux) and half-Fraser broth (bioMerieux) were used as the enrichment media, and PALCAM agar plates (Merck) were used for the determination of the Listerias counts.

The specificity of the ELFA was evaluated on some Listeria spp. and L. monocytogenes strains including type cultures and known serovars from different 
sources, and other gram positive and negative bacteria with the bacterial suspensions at the levels of $10^{7}$ $10^{8} \mathrm{cfu} / \mathrm{ml}$ of sterile saline. All $31 \mathrm{~L}$. monocytogenes strains were found to give positive results, but other Listeria species strains except for $L$. monocytogenes showed negative results to the assay (Table 1 ). Ueda et al. (2006) reported that the prfA 1-2 primer set reacted exclusively with different strains of $L$. monocytogenes, but other primer sets cross-reacted minutely or definitely with several species other than L. monocytogenes. In this study, the results from the ELFA were identical with those of the PCR assay with the prfA 1-2 primer. In this respect, the ELFA was found to be specific to $L$. monocytogenes.

TABLE 1. Specificity of ELFA and PCR to Listeria spp. ${ }^{a}$

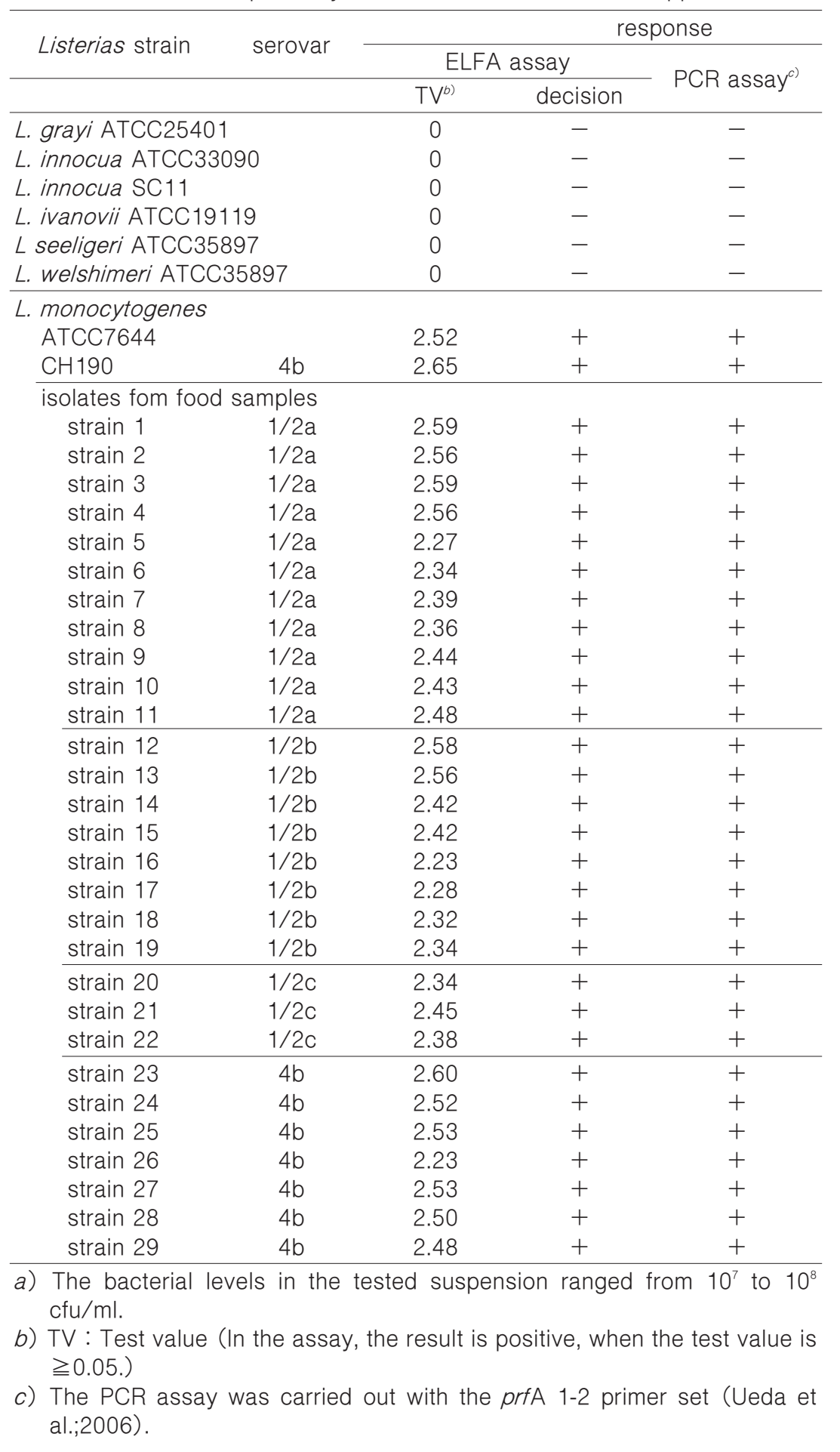


Furthermore, other gram negative and positive bacterial species were assayed as references. All species except Salmonella gave completely negative results to the ELFA (Table 2). However, it was suspected that Salmonella spp. gave false-positive results. If the test values calculated from the relative fluorescence values in the ELFA are less than 0.05, the results of the assays are negative, and if the test values are over 0.05, they are positive results. As the test values were 0.06 or 0.12 , slightly higher than 0.05 for Salmonella, the results were tentatively decided as positive. On the other hand, the values for $L$. monocytogenes were 2.23-2.65 (Table 1, 2). Because the values were distinctly different between Salmonella and L. monocytoges, the results of Salmonella were thought to be false-positive. Since the selective enrichment for $L$. monocytogenes was practically required prior to the ELFA, the assay seemed to be as useful as the magnetic immuno-PCR assay (Ueda et al., 2006).

The sensitivity of the assay system to $L$. monocytogenes $4 \mathrm{~b}$ was examined with different enrichment broth media and various food samples. The enrichment media used were UVM broth, half-Fraser broth and Fraser broth. Food samples used were eggs and egg dishes, milk and dairy products, meat and meat dishes, vegetables, vegetable salads, and fruits and fruit juices. A $10 \%$ suspension of each food sample was prepared with sterile saline solution, except in the case of milk and juices, and these fluid samples were inoculated with $L$. monocytogenes $4 \mathrm{~b}$ at $10^{3}-10^{6} \mathrm{cfu} / \mathrm{ml}$ (Table 3 ). The results of the ELFA were shown to be positive in almost all fluid samples inoculated with $10^{5} \mathrm{cfu} / \mathrm{ml}$, but $10^{6} \mathrm{cfu} / \mathrm{ml}$ was required for the detection of the bacteria in such acidic samples as yoghurt and fruit juices.

TABLE 2. Response of various bacterial species to ELFA for Listeria monocytogenes

\begin{tabular}{|c|c|c|}
\hline Bacterial species/serovar/strain/toxigenicity & $T \bigvee^{e)}$ & decision \\
\hline Escherichia coli O127:H21 (EPEC $\left.{ }^{a}\right)$ & 0.02 & - \\
\hline Escherichia coli O142:NNM (EIEC ${ }^{b)}$ ) & 0 & - \\
\hline Escherichia coli ST and LT producer $\left(\mathrm{ETEC}^{c}\right)$ & 0.03 & - \\
\hline Escherichia coli 0157:H7 (VT1 and VT2 producer) (EHEC ${ }^{d)}$ ) & 0 & - \\
\hline Escherichia coli O157:H7 (VT2 producer) (EHEC) & 0 & - \\
\hline Escherichia coli 0157:H7 (non-VT producer) ATTC43888 & 0 & - \\
\hline Escherichia coli 0111:HNM (VT1 and VT2 producer) (EHEC) & 0 & - \\
\hline Escherichia coli O26:HNM (VT1 and VT2 producer) (EHEC) & 0 & - \\
\hline Escherichia coli from food sample & 0.01 & - \\
\hline Escherichia coli V517 & 0 & - \\
\hline Escherichia coli IFO3301 & 0 & - \\
\hline Klebsiella aerogenes from sewage sample & 0 & - \\
\hline Salmonel/a Enteritidis & 0.12 & $(+)^{f)}$ \\
\hline Salmonella Typhimurium & 0.06 & $(+)^{f)}$ \\
\hline Yersinia enterocolitica & 0 & - \\
\hline Vibrio parahaemolyticus & 0 & - \\
\hline Staphylococcus aureus enterotoxin A producer & 0 & - \\
\hline Staphylococcus aureus enterotoxin B producer & 0 & - \\
\hline Staphylococcus aureus enterotoxin C producer & 0 & - \\
\hline Staphylococcus aureus enterotoxin D producer & 0 & - \\
\hline Staphylococcus aureus enterotoxin E producer & 0 & - \\
\hline Staphylococcus aureus enterotoxin H producer & 0 & - \\
\hline Staphylococcus aureus enterotoxin TSST-1 producer & 0 & - \\
\hline Bacillus cereus : emetic type strain & 0 & - \\
\hline Bacillus cereus : diarrheal type strain & 0 & - \\
\hline Bacillus cereus IFO13484 & 0 & - \\
\hline Bacillus subtilis from air & 0 & - \\
\hline Bacillus licheniformis from air & 0 & - \\
\hline Bacillus licheniformis ATTC43888 & 0 & - \\
\hline Bacillus pumillus from air & 0 & - \\
\hline Clostridium botulinum E type toxin producer & 0 & - \\
\hline Clostridium perfringens Hobbs A type & 0 & - \\
\hline
\end{tabular}

a) Enteropathogenic E. coli ; b) Enteroinvasive E. coli

c) Enterotoxigenic E. coli ; d) Enterohemorrhagic E. coli

e) TV: Test value $f$ ) In the assay, the result is positive, when the test value is $\geqq 0.05$. 
TABLE 3. Detection results of $L$. monocytogenes $4 \mathrm{~b}$ by ELFA from various food suspensions inoculated with different levels of the bacteria.

\begin{tabular}{|c|c|c|c|c|c|}
\hline \multirow{2}{*}{ Food suspension ${ }^{a}$} & \multicolumn{5}{|c|}{ Levels (cfu/ml) of inocula } \\
\hline & Blank & $10^{3}$ & $10^{4}$ & $10^{5}$ & $10^{6}$ \\
\hline \multicolumn{6}{|l|}{ Selective enrichment broth } \\
\hline UVM broth & - & - & + & + & + \\
\hline Half Fraser broth & - & - & + & + & + \\
\hline Fraser broth & - & - & + & + & + \\
\hline \multicolumn{6}{|l|}{ Eggs and their dishes } \\
\hline Liquid whole egg & - & - & + & + & + \\
\hline Thick omelet & - & - & + & + & + \\
\hline \multicolumn{6}{|l|}{ Milk and dairy products } \\
\hline Milk & - & - & + & + & + \\
\hline Yoghurt & - & - & - & - & + \\
\hline Cheese & - & - & + & + & + \\
\hline \multicolumn{6}{|l|}{ Meat and their dishes } \\
\hline Hamburger steak & - & - & - & + & + \\
\hline Roastbeef & - & - & + & + & + \\
\hline Raw beef & - & - & - & + & + \\
\hline Raw pork & - & - & + & + & + \\
\hline Raw chicken & - & - & + & + & + \\
\hline Raw swine liver & - & + & + & + & + \\
\hline \multicolumn{6}{|l|}{ Vegetables } \\
\hline Parsley & - & - & + & + & + \\
\hline Cabbage & - & - & - & + & + \\
\hline Beansprouts & - & - & - & + & + \\
\hline Leek & - & - & - & + & + \\
\hline Welsh onion & - & - & + & + & + \\
\hline Carrot & - & - & + & + & + \\
\hline Tomato & - & - & - & + & + \\
\hline \multicolumn{6}{|l|}{ Vegetable salads } \\
\hline Pumpkin & - & - & + & + & + \\
\hline Okara & - & - & + & + & + \\
\hline Potato & - & - & + & + & + \\
\hline Seafood & - & - & + & + & + \\
\hline \multicolumn{6}{|l|}{ Fruits and their juices } \\
\hline Water melon & - & - & + & + & + \\
\hline Melon & - & - & - & + & + \\
\hline Apple juice & - & - & - & - & + \\
\hline Orange juice & - & - & - & - & + \\
\hline
\end{tabular}

a) All food samples, except milk and juices, were used as a 10 fold-diluted suspension with a sterile saline.

Silbernagel et al. (2004) said that the VIDAS LM02 assay could be completed within $70 \mathrm{~min}$, when the culture sample contained a concentration of $L$. monocytogenes above $10^{5} \mathrm{cfu} / \mathrm{ml}$. Food samples must be enriched in order to increase the number of bacteria to the detectable limit of the assay for a certain time, as it is normal to find bacteria at lower levels than $10^{2} \mathrm{cfu} / \mathrm{g}$ in many kinds of food including milk, meat, fruits and vegetables. The growth of $L$. monocytogenes and the ELFA assay were examined in UVM and half-Fraser broth suspended with several food materials including egg, cheese, raw beef and cabbage. $10^{2} \mathrm{cfu} / \mathrm{ml}$ of $L$. monocytogenes $4 \mathrm{~b}$ was inoculated into the suspension consisting of $1 \mathrm{~g}$ of food material and $9 \mathrm{ml}$ of selective enrichment broth, and incubated at $35^{\circ} \mathrm{C}$. An aliquot of the culture was taken for the ELFA and the determination of the bacterial counts at appropriate intervals during the $12 \mathrm{~h}$ incubation. The bacterial counts increased to $10^{6}-10^{7}$ $\mathrm{cfu} / \mathrm{ml}$ during the 10-12 $\mathrm{h}$ incubation in all suspensions, and the results of the ELFA became positive in the same time (Table 4).

Sakai et al. (2005) showed that the ELFA assay was useful for the detection of $L$. monocytogenes in natural cheese. Also, in the present study, the ELFA was found to be applied satisfactorily as a rapid and 
TABLE 4. Growth of L. monocytogenes $4 \mathrm{~b}$ and ELFA results in selective enrichment media with several food materials added ${ }^{\text {a) }}$

\begin{tabular}{|c|c|c|c|c|c|}
\hline \multirow{2}{*}{$\begin{array}{l}\text { Food materials } \\
\text { inoculated into } \\
\text { selective broth }\end{array}$} & \multirow{2}{*}{$\begin{array}{l}\text { Culture time } \\
\text { (h) }\end{array}$} & \multicolumn{2}{|c|}{ UVM broth } & \multicolumn{2}{|c|}{ Half Fraser broth } \\
\hline & & $\begin{array}{l}\text { Bacterial counts } \\
(\log \mathrm{cfu} / \mathrm{ml})\end{array}$ & Result & $\begin{array}{l}\text { Bacterial counts } \\
(\log \mathrm{cfu} / \mathrm{ml})\end{array}$ & Result \\
\hline \multirow{4}{*}{ Broth alone } & 0 & 2.8 & - & 2.3 & - \\
\hline & 8 & 4.0 & - & 3.4 & - \\
\hline & 10 & 5.6 & - & 4.3 & - \\
\hline & 12 & 6.0 & + & 6.0 & + \\
\hline \multirow{4}{*}{ Liquid whole egg } & 0 & 2.8 & - & 2.7 & - \\
\hline & 8 & 4.5 & - & 4.8 & - \\
\hline & 10 & 5.5 & - & 6.3 & + \\
\hline & 12 & 6.0 & + & NT & \\
\hline \multirow{4}{*}{ Cheese } & 0 & 2.7 & - & 2.1 & - \\
\hline & 8 & 4.3 & - & 4.7 & - \\
\hline & 10 & 5.1 & - & 6.6 & + \\
\hline & 12 & 5.7 & + & NT & \\
\hline \multirow{4}{*}{ Raw beef } & 0 & 2.4 & - & 1.0 & - \\
\hline & 8 & 4.1 & - & 4.8 & - \\
\hline & 10 & NT & & 6.1 & + \\
\hline & 12 & 6.0 & + & NT & \\
\hline \multirow{4}{*}{ Cabbage } & 0 & 2.8 & - & 2.3 & - \\
\hline & 8 & 4.5 & - & 4.7 & - \\
\hline & 10 & 7.2 & + & NT & \\
\hline & 12 & NT & & 5.6 & + \\
\hline
\end{tabular}

a) After $1 \mathrm{~g}$ of food material was added into $10 \mathrm{ml}$ of selective enrichment broth, $L$. monocytogenes $4 \mathrm{~b}$ was inoculated at the level of $10^{2}-10^{3} \mathrm{cfu} / \mathrm{ml}$.

precise method for the detection of $L$. monocytogenes in various food samples, even if the culture had to be enriched for $12 \mathrm{~h}$ prior to the assay.

\section{REFERENCES}

Farber, J. M., and Peterkin, P. I. (1991) Listeria monocytogenes, a foodborne pathogen. Microbiol. Mol. Biol. Rev. 55, 476-511.

Gombas, D. E., Chen, Y., Clavero, R. S., and Scott, V.N. (2003) Survey of Listeria monocytogenes in ready-to-eat foods. J. Food Prot. 66, 559-569.

Kawamoto, K., Makino, S-I., Igimi, S., and Takeshi, K. (2004) The first foodborne outbreak associated with Listeria monocytogenes in Japan. Abstracts of XV International Symposium on Problem of Listeriosis, No.52.

Luchansky, J. B., Call, J. E., Hristova, B., Rumery, L., Yoder, L., and Oser, A. (2005) Viability of Listeria monocytogenes on commercially prepared hams surfaces treated with acidified calcium sulfate and lauric arginate and stored at $4^{\circ} \mathrm{C}$. Meat Sci. 71, 92-99.

McLauchlin, J. (1997) The pathogenicity of Listeria monocytogenes: a public health perspective. Rev. Med. Microbiol., 8, 1-14.

Oktay, H. I., and Heperkan, D. (2006) Evaluation of iso method and VIDAS automated system for identifying Listeria and Salmonella in selected foods. J. Rapid Meth. Auto. Microgiol., 14, 133-145.

Sakai, F., Aoyama, K., Shinozawa, E., Yamagata, H., Maruyama, T., Igimi, S., and Yanahira, S. (2005) Detection of Listeria monocytogenes in natural cheese by Enzyme-Linked fluorescent assay. Jpn. J. Food Microbiol., 22, 17-23.

Silbernagel, K. M., Carver, C. N., Jechorek, R. P., and Johenson, R. L. (2004) Evaluation of VIDAS Listeria monocytogenes // (LM02) Immunoassay method for the detection of Listeria monocytogenes in foods: Collaborative study. J. AOAC Inter., 87, 1123-1132.

Ueda, S., Maruyama, T., and Kuwabara, Y. (2006) Detection of Listeria monocytogenes from food samples by PCR after IMS-plating. Biocont. Sci., 11, 129-134. 